\title{
Management of Termites Using Wood Extractives and Microbes: A Mini Review
}

\author{
Mustansar Mubeen ${ }^{1,2^{*}}$, Yasir Iftikhar ${ }^{2}$, Sunny Ahmar ${ }^{3}$, Aqleem Abbas ${ }^{1}$, Farazia Hassan ${ }^{4}$, Mohammad Murtaza \\ Alami $^{5}$
}

${ }^{1}$ Research Scholar, State Key Laboratory of Agricultural Microbiology and Provincial Key Laboratory of Plant Pathology of Hubei Province, College of Plant Science and Technology, Huazhong Agricultural University, Hubei, P.R. China

${ }^{2}$ Assistant Professor, Department of Plant Pathology, College of Agriculture, University of Sargodha, Sargodha-40100, Pakistan

${ }^{3}$ Research Scholar, National Key Laboratory of Crop Genetic Improvement, College of Plant Science and Technology, Huazhong Agricultural University, Hubei, P.R. China

${ }^{4}$ Student, Department of Bioinformatics, Faculty of Science and Technology, Virtual University of Pakistan, Samundri Campus, Samundri, Pakistan

${ }^{5}$ Student, College of Plant Science and Technology, Department of Crop cultivation and Farming system, Huazhong Agricultural University, Wuhan, Hubei Province, P.R. China

*Address for Correspondence: Mr. Mustansar Mubeen, Research Scholar, State Key Laboratory of Agricultural Microbiology and Provincial Key Laboratory of Plant Pathology of Hubei Province, College of Plant Science and Technology, Huazhong Agricultural University, Wuhan-430070, Hubei, P.R. China

E-mail: mustansar01@yahoo.com

Received: 19 Apr 2019/ Revised: 31 Jul 2019/ Accepted: 29 Aug 2019

\begin{abstract}
Termites play an important role in the world ecosystem. These are of great importance and feed on surface debris such as twigs, bark chips dried grasses, and leaves. These are common wood eaters, damaging the wood and wood bases of building materials. Since the supply of wood is limited, it is necessary to protect the wood and wood products from biological deterioration. Treatment of wood with synthetic chemicals has been a practice to impart durability to the wood. The conventional wood preservatives although are effective against wood destroying organisms but their abundant use has tragic effects on the environment. The relationship between the chemical structure of active components from wood extractives and microbes responsible for termite control, In conclusion, plants showing strong termiticidal activity against these wood-eating bugs.
\end{abstract}

Key-words: Biological deterioration, Wood decay, Termites, Extractives and microorganisms, Termiticidal activity

\section{INTRODUCTION}

Wood is an extremely important natural structural organic material consisting primarily of hemicellulose and cellulose ${ }^{[1]}$. Cellulose, lignin and hemicellulose make three-dimensional biopolymer complex. Most of the chemical and physical properties of wood are due to these biopolymers. Due to its strong physical strength, low cost of processing and aesthetically attractive characters' wood is one of the most preferred materials.

\section{How to cite this article}

Mubeen M, Iftikhar Y, Ahmar S, Abbas A, Hassan F, Alami MM. Management of Termites Using Wood Extractives and Microbes: A Mini Review. SSR Inst. Int. J. Life. Sci., 2019; 5(5): 2410-2419.

Access this article online https://iijls.com/
Nature designed the cellular structure of wood that on weight for weight basis it is as strong as steel. Widespread utilization of wood species in the world is limited because of its low resistance to bio-deterioration ${ }^{[2]}$. Wood is mostly degraded by termites, bacteria and fungi because wood contains lignocellulose as main structural polymer and is well broken down by hindgut bacteria or protozoa of termites ${ }^{[3]}$. Cellulosic plant material is attacked by all termite species ${ }^{[4]}$. The cellulose of wood is easily digested by termite with the help of cellulose decomposing bacteria found in their gut. While searching for their basic food cellulose they can attack non-cellulose materials like rubber, plastics, and even thin metal though these do not serve as their principal food sources and cause significant loss to human interests. Moist wood is attacked by 
subterranean termites and for continuous feeding constant supply of moisture is required. Warmer soil having adequate moisture and contain a large quantity of food are preferred by subterranean termites. These conditions prevail underneath the buildings, which have poor ventilation or insufficient water drainage, or where remainders of lumber, or where roots are left in the soil [5].

Numerous and highly interrelated factors affect wood cellulose consumption by termites. Palatability of wood species is widely accepted factor that influences termites wood consumption rate. Reduction in the structural strength of the buildings occurs because of severe infestations by termites. Termites alone cause more damage than the collective annual damage caused by tornadoes, earthquakes and fires in financial terms. Estimated damage annually exceeds $\$ 3$ billion to the wooden constructions and other cellulosic materials by termites' worldwide ${ }^{[6]}$.

Some wood species have natural resistance against these biological agents, but many kinds of woods are susceptible to this deterioration ${ }^{[7]}$. Preservatives are used to enhance the service life of the susceptible wood. The process of saving the wood from these agents and increasing its service life is called wood preservation ${ }^{[8]}$. Synthetic organic and inorganic compounds like copper chromium arsenate (CCA) and creosote are used to treat wood. These chemicals are not only expensive but also harmful to workers and the environment due to long persistence ${ }^{[9]}$. Natural resistance present in some wood species is due to heartwood extractives in them. Extractives are organic compounds easier to dispose-off and detoxify without having an adverse impact on the environment. Synthetic compounds used in wood preservation are harmful to the environment ${ }^{[8]}$. Plants produce their own defensive chemicals against insects during the process of evolution which are known as extractives ${ }^{[9]}$. Numerous components are present in wood extractives which can be isolated by using polar and non-polar solvents. The durability of wood depends upon toxicity and quantity of extractives present in the wood. Variation in concentrations of extractives is present between different species of woods, individuals of the same species and in a single tree. Sapwoods lack concentration of extractives as compared to heartwood and are thus susceptible to attack by termite and fungi ${ }^{[10]}$. Amount of extractives and composition of chemicals in wood ranges from $2-15 \%$ of the wood weight and their amounts vary between and within the tree species ${ }^{[11]}$. Termites are present all over the warmer regions of the world ${ }^{[12]}$. Subterranean termites are the most vicious species which can cause heavy damage to wooden structures and cellulose materials ${ }^{[13]}$. Subterranean termites live in colonies as social insects. It is considered that sociality in termites occurred due to wood-feeding ${ }^{[4]}$. They are from order Isoptera which means equal wings, referring similar shape size and venation of four wings in an adult. They are polymorphic living in large communities consisting of millions of individuals. They are characterized by cooperative care of young ones, overlapping of generation and presence of division of labour ${ }^{[13]}$. Termites have seven families, Termopsidae, Mastotermitidae, Hodotermitidae Kalotermitidae, Rhinotermitidae, Serritermitidae, and Termitidae [14]. Tropical forests have the highest species richness ${ }^{[15]}$. Plant cellulose material at different stages of decay is the basic food of termites ${ }^{[4]}$. Instead of cellulosic plant material termite also feed on non-cellulosic material causing considerable loss to human interest. Termites are classified as damp wood termites, dry wood termites and subterranean termites. Dry wood termites feed on wood having moisture approximately $13 \%$, damp wood affects decaying wood and subterranean termites infest moist wood and require a continuous supply of moisture and contact with ground soil ${ }^{[13]}$. Termites are also important from agricultural point of view. Various crop plants like maize, sugarcane and fruit trees are infested by termites at different stages of growth ${ }^{[16]}$. Termites were responsible for the degradation of cellulose materials and wood in the terrestrial environment mainly in tropical and subtropical. The principal food of termite was wood and wood products consisting of cellulose such as fabrics, paper wood structure are heavily consumed and destroyed by termites. Therefore emphasis must be given on their control ${ }^{[17]}$. Furthermore termite caused considerable financial damage to wooden structures in Pakistan, thus makes it of public attention. Eleven species described in Pakistan are of a significant threat to timber ${ }^{[18]}$.

Termites are the biggest group of arthropod decomposers playing a pivotal role in nutrient fluxes. Termite bustle improves soil structure. The history of termites control strategies includes the use of physical barriers, wood preservatives, baiting system. 
Liquid termiticides such as arsenical compounds were also popular in use as wood preservatives ${ }^{[19]}$.

Control of termites with Chemical pesticides- Two types of treatment, liquid termiticides and baiting systems, are widely used for the control of subterranean termites. Soil treated with liquid termiticides, such as fipronil, imidacloprid and chlorantraniliprole, places chemical barriers between termites and wooden structures ${ }^{[20]}$. According to 2002 survey, liquid termiticides account for three-fourths of the market share of termite control [21]. Although the effectiveness of liquid termiticides has been proven by laboratory and field studies, Gautam and Henderson ${ }^{[22]}$ are not free from short comings. Soil treatments with liquid termiticides require the use of a large amount of chemical, which not only increases the cost to homeowners but also exerts non-target effects to the soil and aquatic organisms. Baiting systems provide another option for long-term control of subterranean termites. A baiting system will deliver slow-acting pesticides, such as hexaflumuron and noviflumuron, to the whole colony of termites through direct feeding and secondary transfer ${ }^{[23]}$.

Table 1: Termites control by wood extractives

\begin{tabular}{|c|c|c|c|c|}
\hline S. No. & Extractives (Part of wood) & Active ingredients & $\begin{array}{l}\text { Effects on } \\
\text { termites }\end{array}$ & References \\
\hline 1 & Pine and acacia bark extractives & $\begin{array}{c}\text { Gallic acid, catechol, } \\
\text { Rutin }\end{array}$ & Lethal & Tascioglu et al. ${ }^{[24]}$ \\
\hline 2 & $\begin{array}{c}\text { Heartwood extractives of Milicia } \\
\text { excelsa, Albizia coriaria, and } \\
\text { Markhamia lutea }\end{array}$ & $\begin{array}{l}\text { Active ingredient not } \\
\text { checked }\end{array}$ & Lethal & Abbas et al. ${ }^{[25]}$ \\
\hline 3 & $\begin{array}{c}\text { Pinus resinosa, P. strobus, Carya } \\
\text { ovata Mill., Quercus rubra, and } \\
\text { Acer rubrum }\end{array}$ & $\begin{array}{l}\text { Active ingredient not } \\
\text { checked }\end{array}$ & Lethal & Al Fazairy and Hassan ${ }^{[26]}$ \\
\hline 4 & $\begin{array}{c}\text { Bowdichia virgilioides, } \\
\text { Anadenanthera colubrina, and } \\
\text { Hymenaea stigonocarpa }\end{array}$ & $\begin{array}{l}\text { Active ingredient not } \\
\text { checked }\end{array}$ & Lethal & Ayres et al. ${ }^{[27]}$ \\
\hline 5 & Teak (Tectona grandis) & $\begin{array}{c}\text { tannin, quinine and } \\
\text { polyphenol }\end{array}$ & Lethal & Cornelius and Osbrink ${ }^{[28]}$ \\
\hline 6 & $\begin{array}{l}\text { Pinus densiflora, Azadirachta } \\
\text { indica }\end{array}$ & $\begin{array}{l}\text { Active ingredient not } \\
\text { checked }\end{array}$ & Repellent & Culliney and Grace ${ }^{[29]}$ \\
\hline
\end{tabular}

Extractives from wood and bark have the ability to replace synthetic wood preservatives [30]. There are various benefits of using wood extractives as preservatives to increase the service life of the wood. Various factors are responsible for the durability of wood related to conditions within it. Water-soluble components in the wood are also included in extractives rather than lignin, cellulose and hemicellulose. Lignans, polyphenolics and tannins are toxic chemicals against insect and fungi naturally present in wood extractives. These chemicals have been observed safe to human and environment ${ }^{[9]}$. There are various chemicals present in wood, which enhance its durability and have adverse effects on invading insects like Tannins, terpenes, phenolic compounds and lignin. Terpenoids is the largest class of chemicals present in the wood. These are used as an insect repellent, flavoring agents and fungicides. Phenolic compounds are present in heartwood, sapwood and bark. They act as a repellent against insects and fungus ${ }^{[31]}$. Heartwood of some tree species is rich in polyphenolics ${ }^{[32]}$. A large number of phenols is a structural unit of polyphenolics and is present naturally but also semi synthetic and synthetic forms are available. Physical, biological and chemical properties of a specific class of polyphenolics are determined by the number of phenols present in it. Tannins are the subset of phenolics 
including tannic acid and ellagitannin [33]. Various condensed tannins based on catechin-gallocatechin polymers, D-gallocatechin, D-catechin, leucocyanidin leucopelargonidin, leucodelphinidin and gallic acid in the bark of oak ( $Q$. rubra). Water, acetone and hexane extracts of oak bark had antifungal and anti-termetic property. Gallic acid, glucose, D-catechin, pyrocyanidin, pyrogallol, $p$-sitosterol catechin and tannins were present in Red maple (A. rubrum). Bark extracts (A: $\mathrm{H}: \mathrm{W}$ ) of red maple showed a little antifungal and anti-termitic property. Tannin like compound was present in pine bark which had fungistatic and termiticidal effects ${ }^{[32]}$. Bark and wood of some tree species naturally have condensed tannins which acted as wood preservatives [33]. Bark extracts from Pinus taeda containing condensed tannin and copper complex had effective results as wood preservatives termites and fungus concluded that halogenated tannin extracts from the plant have ability to combat against fungi, rotting and insects specially termites ${ }^{[34]}$.

The structure and effect of condensed tannins from 16 woody plants were checked on six herbivorous insect species including termites. Tannin structure varied a lot even congeneric plant species have different tannin structure ${ }^{[35]}$. Anti-herbivore activity of tannin differed markedly. Different effects from the same tannin were observed on herbivores due to interaction between gut physiology of insects and tannin structure. The combination of three chemicals like- sulfited wattle tannin, cashew nut shell liquid and copper chloride to develop a preservative against termites, which has no impact upon the environment. These chemicals were tested against wooden logs of soft wood of Populus tremula and Pinus ponderosa in different concentrations of tannin alone or combined with copper chloride and cashew nut shell liquid used on logs of two species. Combination of four $40 \% \mathrm{CNSL}+2 \% \mathrm{CuCl}_{2}$ and $\mathrm{CNSL}+1 \%$ $\mathrm{CuCl}_{2}$ expressed minimal damage by termites after 108 days. A researcher ${ }^{[36]}$ checked the capability of tannin from wood and copper complexes and chemically modified tannin to infiltrate into the wood and their capability to defend against termites. Tannin- $\mathrm{NH}_{3}-\mathrm{Cu}$ mixture exhibited contact mortality for termites in the contact toxicity experiment. Resorcinolated tannin (RMT) expressed $100 \%$ mortality in wood eating-damage test. RMT and catecholated tannin (CMT) alone or mixed with ammonia cooper shown good penetrability and termite resistance in field stake test ${ }^{[37]}$. A adhesive, which had no adverse impact on environment consisting cornstarch and tannin to enhance the resistance of composite against Coniophora puteana rot fungi and Coriolus versicolor. Also addition of borax in $0.5 \%, 2 \%$, and $1 \%$ $(\mathrm{w} / \mathrm{w})$ was done in cornstarch and tannin. The result showed that an increased amount of borax in adhesive decreased the mechanical properties of composite. Studies on biodegradation were also performed results showed that wood impregnated in borax at $0.5 \%$ in addition to tannin and cornstarch in adhesive improves the resistance of wood composite against $C$. puteana and C. versicolor. The anti-termitic activity of extractives from $B$. virgilioides, $H$. stigonocarpa, and $A$. colubrina against termites Nasutitermes corniger and concluded that all extractives tested in laboratory had anti-termitic chemical against termite species ${ }^{[38]}$. Ismayati et al. ${ }^{[39]}$ conducted a study of temperature treated Pinus wallichiana (kail), Fagus grandifolia (beech), Cedrus deodara (diar), and Abies pindrow (pertal) for the first food choice and preference by $O$. obesus (Isoptera: Termitidae). They concluded that temperature treatment of the woods by incubating at different temperature 50 , 70,90 , and $100^{\circ} \mathrm{C}$ for 24 and 48 hours could be a useful strategy to protect wooden structures from termite damage. Termites have a preference wood containing specific moisture. The wood treated at definite temperature for a specific period had reduced moisture and became less edible to the termites. Palatability of different woods was influenced by the temperature when incubated at $1000^{\circ} \mathrm{C}$ for 24 and 48 hours, particularly for Beech and Kail wood consumption and heat treatment, expressed an inverse correlation between one another. Diar and Pertal were less chosen by termites, whereas Kail and Beech were the preferred woods for the termites. Kaya and Gaugler ${ }^{[40]}$ examined the extractive contents of teak ( $T$. grandis) wood against termites. Extractive contents were determined by gradual extraction using $n$-hexane, ethyl acetate, and methanol. Results showed that greater ethyl acetate extractive contents exhibited higher termite resistance. Ethyl acetate extractives had tannin which caused termite repellency. Further, Khan et al. ${ }^{[41]}$ checked the function of extractives in the durability of wood. Eight species of wood having natural durability and control of non-durable wood were tested against the decay by three white-rot and three brown-rot fungi and termites 
attack in laboratory soil block test. Higher weight loss was exhibited by all wood species from which extractives were removed due to termites and fungus attack. Weight losses from extracted samples were comparable to weight losses from non-durable control. Evaluation of ethanol seed extracts of fifteen medicinal plants against termites revealed that saponins, flavonoids, alkaloids and tannins contents were found to be ranged from 0.54 to $8.60 \%, 0.65$ to $15.18 \%, 0.34$ to $12.47 \%$, and 0.08 to $27.71 \%$, respectively ${ }^{[26]}$. Extracts of eleven seeds of plants species Foeniculum vulgare, Peganum harmala, Psoralea corylifolia, Mentha sp., Ocimum basilicum, Allium sativum, Cichorium intybus, Capsicum frutescens, Plantago ovate, A. indica and Melia azadirachta have Tannin. Bioassay results showed that seed extracts of these eleven plants species have expressed high antitermitic activity. In conclusion, Acacia mearnsii has more tannin as compared to $A$. crassicarpa. To check the termite feeding deterrent ability three choice feeding tests with condensed tannin and hydrolyzable tannin, ethyl acetate extract (EA) and water-soluble extract (WS) were used. Both $70 \%$ acetone extracts from $A$. crassicarpa and $A$. mearnsii were excellent as termite controlling agent. A. mearnsii was comparatively more effective as compared to $A$. crassicarpa ${ }^{[42]}$.

\section{Use of microorganisms for controlling termites}

Bacteria- The most widely used microbial control agent for control of pest Lepidoptera, Coleoptera, and Diptera insects is $B$. thuringiensis. The insecticidal proteins of $B$. thuringiensis are highly specific insect gut toxins with a superior safety record in regard to their effects on nontarget organisms ${ }^{[43]}$.

Workers of M. championi (Snyder) (Termitidae) and $\mathrm{H}$. indicola (Wasmann) (Rhinotermitidae) suffered 100\% mortality within 13 days of exposure to two local strains of $B$. thuringiensis in laboratory tests. Termites such as $H$. indicola, M. championi, and Bifiditermes beesoni (Gardner) (Kalotermitidae) are highly susceptible to infection of $B$. thuringiensis (Bt), a commercial preparation of Bt (Thuricide-HP concentrate), exhibiting $100 \%$ mortality within 6 days of exposure. Laboratory colonies of $M$. championi, $H$. indicola, and $B$. beesoni exposed to suspensions of the spore-forming bacterium S. marcescens Bizio succumbed completely 7-13 days following infection ${ }^{[44,45]}$. The pathogenicity of $P$. aeruginosa (Schroeter) against M. championi, H. indicola, and C. heimi (Wasmann) (Rhinotermitidae) were checked in the laboratory. Termite mortality ranged from $25-52 \%$ in 7 days post-inoculation to $84-100 \%$ in 25 days postinoculation. The authors concluded that $P$. aeruginosa is "fairly" pathogenic to the three termite species, although the bacterium's potential as a biological control agent is limited by its occasional status as a plant pathogen. $S$. marcescens isolate T8 was highly virulent at the concentration $10 \mathrm{cfu} / \mathrm{ml}$ for the $C$. formosanus. Termite mortality was $24 \%$ by 2 days and $99 \%$ after 19 days of the experiment ${ }^{[46]}$. Furthermore biological control agents from dead termites and revealed the presence of 15 bacteria and one fungus in dead termites. Multiple strains of $S$. marcescens were isolated and six out of eight strains of $S$. marcescens were reported as biological control agents for $C$. formosanus Shiraki ${ }^{[47]}$. Bacteria isolated from termite substrata included $C$. urealyticum Pitcher, A. calcoacet/baumanni/Gen2 (Beijerinck), S. marcescens, and E. gergoviae Brenner found that three HCN-producing rhizo-bacterial species, i.e., $R$. radiobacter, $A$. latus, and $A$. caviae killed $O$. obesus subterranean termites under in vitro conditions ${ }^{[48]}$. Furthermore a researcher reported enhancement in virulence of $B$. thuringiensis (about 1.5-1.8) and $S$. marcescens $(1.3-1.6)$ by $1 \%$ potassium chloride or $1 \%$ sodium citrate against the workers of $M$. championi and caused mortality of termites ${ }^{[49]}$. LT50, LT90 and virulence enhancement ratio showed that $1 \%$ sodium citrate when mixed with S. marcescens caused quicker rate of mortality of termites as compared to the mixture of $1 \%$ potassium chloride and S. marcescens. Boric acid (at $1 \%$ concentration) was also found more effective to enhance the pathogenicity of $B$. thuringiensis against various species of termites. A researcher used indigenous gut bacteria Enterobacter cloacae of the Formosan subterranean termite, C. formosanus Shiraki (Isoptera: Rhinotermitidae) as shuttle system to deliver, express, and spread foreign genes in termite colonies. The gut bacterium was transformed with a recombinant plasmid (pEGFP) containing genes encoding ampicillin resistance and green fluorescent protein (GFP). In laboratory experiments, termite workers and soldiers from three colonies were fed with filter paper inoculated with transformed bacteria. Transformed bacteria were detected in termite guts by growing the entire gut flora under selective conditions and checking the cultures visually for fluorescence. It was demonstrated that (a) transformed bacteria were ingested within a few hours 
and the GFP gene was expressed in the termite gut; (b) transformed bacteria established a persistent population in the termite gut for up to 11 weeks; (c) transformed bacteria were efficiently transferred throughout a laboratory colony, even when the donor (termites initially fed with transformed bacteria) to recipient (not fed) ratio was low; and (d) transformed E. cloacae were transferred into soil; however, they did not accumulate over time and the GFP plasmid was not transferred to other soil bacteria. In the future, transgenic bacteria may be used to shuttle detrimental genes into termite colonies for improved pest control ${ }^{[50]}$.

Fungi- In recent years, much research interest has focused on the use of fungal agents for pest control Some 700 species of entomopathogenic fungi have been reported and at least 22 species of fungi are obligate ectoparasites of termites ${ }^{[51]}$. The sporulation of 22 total isolates of $M$. anisopliae and B. bassiana were quantified on cadavers of the Formosan subterranean termite, $C$. formosanus. Conidial production increased significantly over 11 day's post-death ${ }^{[52]}$. Effects of isolates of $M$. anisopliae and $B$. bassiana on in vivo sporulation were significant. In vitro and in vivo sporulation differed by as much as 89 and 232 among the selected isolates of $M$. anisopliae and $B$. bassiana, respectively. A single fungal isolate, C4-B, taxonomically identified as $M$. anisopliae (Metschnikoff) was found to cause rapid mortality on Formosan subterranean termite alates ${ }^{[53]}$. In initial experiments, C4-B was more lethal to both alates and workers compared with $M$. anisopliae strains ESC 1, previously marketed as the termite biocontrol agent, BioBlast. Dose-response assays in which Formosan subterranean termite alates were exposed to a known concentration of C4-B spores revealed that 106 spores $/ \mathrm{ml}$ killed $100 \%$ of the alates in 3 days, both $10^{5}$ and $10^{4} \mathrm{spores} / \mathrm{ml}$ in 6 days, 103 spores $/ \mathrm{ml}$ in 9 days, and 100 spores $/ \mathrm{ml}$ in 12 days. Assays with workers demonstrated that 106 and 105 spores/ml killed $100 \%$ of the workers in 6 days. In an experiment to test the transfer of inoculum from infected workers to uninfected nest mates, $62.8 \%$ of the workers died in 21 days when only $20 \%$ of the workers had been inoculated. Mortality of alates caused by C4-B was tested at two field sites by dispersing fungal spores on grassy lawns and collecting alates from the treated areas. Alates thus infected showed $100 \%$ mortality by day 5 , whereas only $64.8 \%$ of untreated control Alates from the same collection area was dead on that day.

Viruses- A large number of viruses offers potential as microbial control agents of insects ${ }^{[54]}$. Those with the greatest microbial control potential are in the Baculoviridae (nuclear polyhedrosis viruses and granuloviruses). More than 400insect species, mostly in the Lepidoptera and Hymenoptera, have been reported as hosts for baculoviruses. However, the viral infection of termites has been little reported. A virus was isolated which was Coptotermes lacteus (Froggatt) (Rhinotermitidae), which was similar to acute paralysis virus of the honey bee Apis mellifera Linnaeus (Hymenoptera: Apidae) ${ }^{[35]}$. A nuclear polyhedrosis virus, obtained from caterpillars of Spodoptera littoralis Boisduval (Lepidoptera: Noctuidae), was infective to a laboratory colony of $K$. flavicollis (Fabricius) (Kalotermitidae) ${ }^{[55,56]}$. Termites died 2-10 days postinfection under laboratory conditions and the authors suggested that control of $K$. flavicollis with NPV might be feasible. However, the potential of viruses for termite control has yet to be evaluated in the field [56,57]. Accessibility of the pest to be controlled is the prime factor affecting the efficacy of viral pathogens. Insects that feed openly on the foliage of host plants are most easily treated and the most promising results have been obtained against pest of this type (e.g., caterpillar's sawfly larvae). Insects living in concealed habitats, such as the soil, are most difficult to infect. The efficacy, specificity, and production of secondary inoculum make baculoviruses attractive alternative to broad-spectrum insecticides and ideal components of integrated pest management (IPM) systems due to their lack of untoward effects on beneficial insects including other biological control organisms ${ }^{[58]}$. Unfortunately, there are other drawbacks to the use of viruses to suppress pest populations: viruses kill their hosts slowly compared to other pathogens; environmental factors such as rainfall and solar radiation may reduce viral persistence in soil; mass production of viruses is hampered by the need for living hosts or tissue culture, lastly, viral formulations have had difficulty in competing successfully, on the basis of performance and cost, with other pest control products such as chemical insecticides or even other microbial agents ${ }^{[59,60]}$. 
Nematode-Entomopathogenic nematodes are nonsegmented, soft bodied roundworms that are facultative or sometimes parasites obligate of insects. Entomopathogenic nematodes occur physically in soil environments and find their host in response to vibration, carbon dioxide and other chemical cues [61] species in two families (Steinernematidae and Heterorhabditidae) have been successfully used as natural insecticides in pest management programs ${ }^{[62]}$. Four species of entomopathogenic nematodes Steinernema riobrave, S. carpocapsae, Heterorhabditis bacteriophora and $H$. indica gives effective control against subterranean termites, Coptotermes formosanus (Shiraki) and Reticulitermes flavipes (Kollar) in Petri dish tests ${ }^{[62]}$.

\section{CONCLUSIONS}

This review explains the termite control options used now-a-days and in the past. The chemical method of control is the most popular and effective. But the deleterious effect of chemicals on our environment cannot be ignored. Therefore, for the safety of living beings and the environment, we should search for ecologically safe alternatives and exploit the potential of the non-chemical measures that have been studied by other researchers. The plants investigated by different workers having strong termiticidal activity can be further used individually and in combination. The active component responsible for termite control can be extracted to prepare potent bio-pesticidal formulations.

Few studies relate the structure of the active component with anti-termite activity and enable us to explore the chemical structure of active components before their testing on termite species. Plant extracts could be exploited to develop new wood preservatives. Further field-level studies are required to use these botanicals as commercial termiticides.

\section{ACKNOWLEDGMENTS}

The authors are grateful to the Huazhong Agricultural University, China and University of Sargodha, Pakistan for providing learning facilities.

\section{CONTRIBUTION OF AUTHORS}

Research concept- Mustansar Mubeen, Aqleem Abbas

Research design- Mustansar Mubeen, Aqleem Abbas

Supervision- Yasir Iftikhar

Data collection- Yasir Iftikhar, Sunny Ahmar, Mohammad
Murtaza Alami

Data analysis and Interpretation- Yasir Iftikhar, Sunny Ahmar, Mohammad Murtaza Alami

Literature search- Farazia Hassan

Writing article- Farazia Hassan

Critical review- Farazia Hassan

Article editing- Mustansar Mubeen, Yasir Iftikhar, Sunny Ahmar, Aqleem Abbas, Farazia Hassan, Mohammad Murtaza Alami

Final approval- Mustansar Mubeen, Yasir Iftikhar, Sunny Ahmar, Aqleem Abbas, Farazia Hassan, Mohammad Murtaza Alami

\section{REFERENCES}

[1] Chang ST, Hon DNS, Feist WC. Photodegradation and photoprotection of wood surfaces. Wood Fiber Sci., 2007; 14: 104-17.

[2] Oberst S, Lenz M, Lai JC, Evans TA. Termites manipulate moisture content of wood to maximize foraging resources. Biol. Lett., 2019; 15(7): 20190365.

[3] Schultz TP, Nicholas DD. Development of environmentally-benign wood preservatives based on the combination of organic biocides with antioxidants and metal chelators. Phytochem., 2002; 61: 555-60.

[4] Abe T, Bignell DE, Higashi M. Termites: evolution, sociality, symbioses, ecology. Springer Sci. Business Media, 2000.

[5] Peterson C, Gerard P, Wagner T. Charring does not affect wood infestation by subterranean termites. Entomol. Exp. Appl., 2008; 126: 78-84.

[6] Su NY. Novel technologies for subterranean termite control. Sociobiol., 2002; 40: 95-102.

[7] Kityo P, Plumptre R. The Uganda timber users' Handbook: a guide to better timber use. Commonwealth Secretariat, 1997.

[8] Barnes H. Wood protecting chemicals from the 21st century. International Research Group on Wood Preservation. 24 $4^{\text {th }}$ Annual Conference Meeting at Orlando, Florida, USA. 1992; 16-20.

[9] Arango RA, Green III F, Hintz K, Lebow PK, Miller RB. Natural durability of tropical and native woods against termite damage by Reticulitermes flavipes (Kollar). Int. Biodeter. Biodegr., 2006: 57: 146-50.

[10]Hinterstoisser B, Stefke B, Schwanninger M. Wood: Raw material-material-source of energy for the future. Lignovisionen., 2000; 2: 29-36. 
[11]Myer A, Brian TF. Evidence for the role of subterranean termites (Reticulitermes spp.) in temperate forest soil nutrient cycling. Ecosystems, 2019; 22(3): 602-18.

[12]Nunes L, Nobre T. Strategies of subterranean termite control in buildings.in 3rd International Seminar on Historical Constructions. Guimaraes., 2019.

[13]Henderson G, Fei $H$. Comparison of native subterranean termite and Formosan subterranean termite: biology ecology and methods of control. Enhancing the Durability of Lumber and Engineered Wood Products Conference. Forest Products Society, Madison, WI Orlando, FL., 2002; 11-13.

[14]Donovan SE, Eggleton P, Dubbin WE, Batchelder M, Dibog L. The effect of a soil-feeding termite, Cubitermes fungifaber (Isoptera: Termitidae) on soil properties: termites may be an important source of soil microhabitat heterogeneity in tropical forests. Pedobiologia., 2001; 45: 1-11.

[15]Eggleton P. Global patterns of termite diversity. Termites: evolution, sociality, symbioses, ecology. Springer, 2000; pp. 25-51.

[16]Mitchell JD. Termites as pests of crops, forestry, rangeland and structures in southern Africa and their control. Sociobiol., 2002; 40: 47-69.

[17]Peralta RCG, Menezes EB, Carvalho A, Menezes E. Feeding preferences of subterranean termites for forest species associated or not to wood decaying fungi. For. Environ., 2003; 10: 58-63.

[18]Manzoor F, Chaudhary M, Sheikh N, Khan IA, Khan T. Diversity and proportion of termite species in garden trees and wheat crop in District Bhakkar, Pakistan. Pak. J. Zool., 1993; 43.

[19]Preston AF. Wood preservation. Forest Products J., 2000; 50: 12.

[20]Ibrahim SA, Henderson G, Fei H. Toxicity, repellency, and horizontal transmission of fipronil in the Formosan subterranean termite (Isoptera: Rhinotermitidae). J. Econo. Entomo., 2003; 96: 46167.

[21]Rust MK, Su NY. Managing social insects of urban importance. Ann Rev Entomo., 2012; 57: 355-75.

[22]Gautam BK, Henderson G. Wood consumption by Formosan subterranean termites (Isoptera: Rhinotermitidae) as affected by wood moisture content and temperature. Ann. Entomol. Soc. Am., 2011; 104: 459-64.
[23]Connick Jr WJ, Osbrink WL, Wright MS, Williams KS, Daigle DJ, et al. Increased mortality of Coptotermes formosanus (Isoptera: Rhinotermitidae) exposed to eicosanoid biosynthesis inhibitors and Serratia marcescens (Eubacteriales: Enterobacteriaceae). Environ. Entomo., 2001; 30: 449-55.

[24]Tascioglu C, Yalcin M, de Troya TH. Sivrikaya. Termiticidal properties of some wood and bark extracts used as wood preservatives. BioResources, 2012; 7: 2960-69.

[25]Abbas M, Shahid M, Iqbal M, Anjum F, Sharif S, et al. Antitermitic activity and phytochemical analysis of fifteen medicinal plant seeds. J. Med. Res., 2013; 7: 1608-17.

[26]Al Fazairy AA, Hassan F. Histopathology of termite Kalotermes flavicollis Fabr. infected with a nuclear polyhedrosis virus. Int. J. Tropical Insect Sci., 1993; 14: 127-34.

[27]Ayres MP, Clausen TP, MacLean SF, Redman AM, Reichardt PB. Diversity of structure and antiherbivore activity in condensed tannins. Ecol., 1997; 78: 1696-712.

[28]Cornelius ML, Osbrink WL. Tunneling Behavior, Foraging Tenacity, and Wood Consumption Rates of Formosan and Eastern Subterranean Termites (Isoptera: Rhinotermitidae) in Laboratory Bioassays. Sociobiol., 2001; 37: 79-94.

[29]Culliney T, Grace J. Prospects for the biological control of subterranean termites (Isoptera: Rhinotermitidae), with special reference to Coptotermes formosanus. Bull. Entomol. Res., 2000; 90: 09-21.

[30]Cunningham JC. Baculoviruses as microbial insecticides, in R. Reuveni, editor. Novel Approaches to Integrated Pest Management. CRC Press, Boca Raton, Florida, USA, 1995; pp. 261-92.

[31]Dean R, Van Kan JA, Pretorius ZA, Hammond-Kosack $K E$, Di Pietro $A$, et al. The Top 10 fungal pathogens in molecular plant pathology. Mol. Pla. Patho., 2012; 13: 414-30.

[32] Law S, Eggleton P, Griffiths H, Ashton L. Parr C. Suspended dead wood decomposes slowly in the tropics, with microbial decay greater than termite decay. Ecosyst., 2019; pp. 01-13.

[33]Devi KK, Seth N, Kothamasi S, Kothamasi D. Hydrogen cyanide-producing rhizobacteria kill subterranean termite Odontotermes obesus 
(Rambur) by cyanide poisoning under in vitro conditions. Curr. Micro., 2007; 54: 74-78.

[34]Nutting WL. Foraging Behavior of Subterranean Termites. Insect Behavior: A Sourcebook of Laboratory and Field Exercises, 2019; 11.

[35]Grace JK. Biological control strategies for suppression of termites. J. Agric. Entomol., 1997; 14: 281-89.

[36]Harun J, Labosky P. Antitermitic and antifungal properties of selected bark extractives. Wood Fiber Sci., 2007; 17: 327-35.

[37]Evans TA, Kasseney BD. The Dominance Hierarchy of Wood-Eating Termites from China. Insects, 2019; 10: 210. doi: $10.3390 /$ insects 10070210.

[38]Husseneder C, Grace JK. Genetically engineered termite gut bacteria (Enterobacter cloacae) deliver and spread foreign genes in termite colonies. App. Micro. Biotech., 2005; 68: 360-67.

[39]Ismayati M, Nakagawa-izumi A, Ohi H, Tarmadi D. Efficacy of tannin extracts isolated from acacia bark waste against the subterranean termite Coptotermes gestroi Wasmann. Proceedings of the $10^{\text {th }}$ PacificTermite Research Group Conference, 2014; S3: 5.

[40]Kaya HK, Gaugler R. Entomopathogenic nematodes. Ann. Review Entomol., 1993; 38: 181-206.

[41]Khan K, Jafri R, Ahmad M. Role of trophallaxis in the dispersal of radioactive I 131 and of bacterial infections in the termite, Bifiditermes beesoni. Material und Organismen., 1981; 16: 189-97.

[42]Khan K, Jafri R, Ahmad M, Khan K. The pathogenicity of Pseudomonas aeruginosa against termites. Pak. J. Zool., 1992; 24: 243-45.

[43]Khan KI, Jafri RH, Ahmad M. Discovery and pathogenicity of Pseudomonas fluorescens against various species of termites. Punjab Univ. Pak. J. Zool., 2008; 23: 047-57.

[44]Bal K Gautam, Gregg H. Relative Humidity Preference and Survival of Starved Formosan Subterranean Termites (Isoptera: Rhinotermitidae) at Various Temperature and Relative Humidity Conditions. Environ. Entomol., 2011; 40(5): 1232-38.

[45]Kirker G, Blodgett A, Arango R, Lebow P, Clausen C. The role of extractives in naturally durable wood species. Int. Biodeter. Biodegr., 2013; 82: 53-58.

[46]Lacey L, Goettel M. Current developments in microbial control of insect pests and prospects for the early $21^{\text {st }}$ century. Entomophaga., 1995; 40 : 03-27.
[47]Godfrey Rotich, Fredrick M. Wanjala. Comparative Efficacy of Varied Concentrations Imidacloprid in the Laboratory Management of Termites (Microtermes natalensis). Asian J. Resear. Zool., 2019; pp. 1-5.

[48]Lotz WR. Wood preservation systems including halogenated tannin extracts. Google Patents, 1993.

[49] Lukmandaru G. Variability in the natural termite resistance of plantation teak wood and its relations with wood extractive content and color properties. J. Forest. Res., 1993; 8: 17-31.

[50]McGraw BA, Koppenhöfer AM. Evaluation of two endemic and five commercial entomopathogenic nematode species (Rhabditida: Heterorhabditidae and Steinernematidae) against annual Bluegrass weevil (Coleoptera: Curculionidae) larvae and adults. Biological Cont., 2008; 46: 467-75.

[51]Sun J, Fuxa J, RHenderson, G. Sporulation of Metarhizium anisopliae and Beauveria bassiana on Coptotermes formosanus and in vitro. J. Invert. Patho.m 2002: 81: 78-85.

[52]Moubarik A, Charrier B, Charrier F, Pizzi A, Allal A. Evaluation of decay resistance of wood products made from borax-impregnated wood and bonded with a formaldehyde-free cornstarch and tannin adhesive. Ann. Forest Sci., 2009; 66: 1.

[53]Jurgensen MF, Miller CA, Trettin CT, Dumroese DS. Bedding of Wetland Soil: Effects of Bed Height and Termite Activity on Wood Decomposition. Soil Sci. Soc. Am. J., 2019; pp. 1-10. doi: 10.2136/sssaj2018.12.0492.

[54]Mwalongo GC, Mkayula LL, Mubofu EB, Mwingira BA. Preventing termite attack. Environmentally friendly chemical combinations of cashew nut shell liquid, sulfited wattle tannin and copper (II) chloride. Green Chem., 1999; 1: 13-16.

[55]Ngee PS, Tashiro A, Yoshimura T, Jaal Z, Lee CY. Wood preference of selected Malaysian subterranean termites (Isoptera: Rhinotermitidae, Termitidae). Sociobiol., 2004; 43: 535-50.

[56]Ohmura W, Ozaki M, Yamaoka R. Behavioral and electrophysiological investigation on taste response of the termite Zootermopsis nevadensis to wood extractives. J. Wood Sci., 2006; 52: 261-64.

[57]Pimentel D, McNair M, Buck L, Pimentel M, Kamil J. The value of forests to world food security. Human Ecol., 1995; 25: 91-120. 
[58]Zhao, Z, Dong R, Chungkun S. Termitoidae-Termites. Rhythms of Insect Evolution: Evidence from the Jurassic and Cretaceous in Northern China, Paleobiol. Geobiol., 2019: 113-19.

[59]Rowell RM. Handbook of wood chemistry and wood composites. CRC press, 2012.

[60]Santana AL, Maranhao CA, Santos JC, Cunha FM, Conceição $\mathrm{GM}$, et al. Antitermitic activity of extractives from three Brazilian hardwoods against Nasutitermes corniger. Int. Biodeterior. Biodegradation, 2010; 64: 07-12.
[61]Sheikh N, Mahmood QA, Umair ML, Manzoor F. Study of temperature treated woods for the preference and first food choice by Odontotermes obesus (Isoptera: Termitidae). Sociobiol., 2010; 56: 363.

[62]Syofuna A, Banana IS, Nakabonge G. Efficiency of natural wood extractives as wood preservatives against termite attack. Woods Sci. Technol., 2012; 14(2): 155-63. doi: 10.4067/S0718221X2012000200003. 